\title{
INTERFERENSI FONOLOGIS BAHASA TOLAKI DALAM BAHASA INDONESIA SISWA KELAS X SMA NEGERI 1 TONGAUNA
}

\author{
Ramlin \\ Universitas Lakidende Unaaha \\ e-mail: spdramlin@gmail.com
}

\begin{abstract}
ABSTRAK
Interferensi adalah adanya kemiripan beberapa kata terutama bahasa-bahasa, yang masih serumpun. Seperti halnya suku- $\neg$ suku bangsa di Indonesia lainnya, sebagian besar masyarakat suku tolaki di samping menggunakan bahasa daerah sebagai alat komunikasi juga menggunakan bahasa Indonesia. Namun, dalam penggunaan kedua bahasa tersebut ada yang mampu menggunakannya sesuai dengan norma-norma masing-masing bahasa tersebut, tetapi adapula yang kurang mampu, terutama siswa sekolah menengah atas yang belajar bahasa Indonesia sebagai bahasa kedua. Pemakaian bahasa Indonesia oleh siswa tersebut akan dipengaruhi oleh bahasa tolaki, baik sistemnya maupun dalam bentuk bunyinya. Masalah penelitian ini adalah "Interferensi Fonologis Bahasa Tolaki dalam Penggunaan Bahasa Indonesia Siswa Kelas X SMA Negeri 1 Tongauna". Tujuan penelitian ini untuk memperoleh data dan informasi yang jelas tentang interferensi fonologis bahasa tolaki dalam penggunaan bahasa Indonesia siswa kelas X SMA Negeri 1 Tongauna. Manfaat penelitian ini yaitu dapat memberikan informasi faktual tentang kemampuan menggunakan bahasa Indonesia siswa kelas X SMA Negeri 1 Tongauna, sebagai bahan masukan bagi pengambil kebijakan dalam upaya meningkatkan pembelajaran bahasa Indonesia di SMA dan sebagai bahan informasi bagi peneliti selanjutnya yang sifatnya lebih mendalam dan relevan dengan objek penelitian ini. Jenis Penelitian ini penelitian lapangan karena peneliti terlibat langsung dilapangan atau ke sekolah tempat sampel untuk mengumpulkan data penelitian. Data penelitian ini adalah data lisan yakni berupa tuturan bahasa Tolaki yang disampaikan dalam bercerita oleh siswa kelas $\mathrm{X}$ SMA Negeri 1 Tongauna, yang direkam melalui tape recorder. Sumber data penelitian ini adalah semua siswa kelas X SMA Negeri 1 Tongauna sebagai penutur asli yang menggunakan bahasa daerah Tolaki sebagai bahasa ibu atau bahasa pertama. Teknik pengumpulan data yang digunakan dalam penelitian ini adalah teknik observasi, teknik rekam dan teknik wawancara. Hasil penelitian yang diperoleh dari penelitian ini adalah (1) penghilangan fonem, (2) penggantian dan penghilangan fonem, (3) penggantian fonem, (4) interpretasi hasil penelitian.
\end{abstract}

Kata Kunci: Interferensi; Fonologis; Bahasa. 


\section{LATAR BELAKANG}

Pemakaian bahasa sebagai alat komunikasi merupakan tanda kemampuan berbahasa yang hanya dimiliki oleh manusia. Namur, kemanpuan berbahasa harus diusahakan dan harus dipelajari secara formal maupun informal sebelum manusia memiliki kemampuan itu. Bahasa daerah sebagai bagian dari kebudayaan nasional berfungsi antara lain sebagai alat komunikasi antarwarga satu suku, meskipun dalam kegiatan komunikasi tertulis sebagian besar menggunakan bahasa Indonesia. Di samping itu, bahasa daerah juga berfungsi sebagai bahasa pengantar di sekolah terutama dikelas $\neg$-kelas permulaan utamanya dibeberapa daerah pedesaan.

Salah satu bahasa daerah Sulawesi Tenggara adalah bahasa Tolaki. Bahasa Tolaki merupakan bahasa daerah yang memiliki fungsi dan kedudukan cukup penting dalam kehidupan masyarakat Tolaki. Bahasa ini berfungsi sebagai bahasa ibu, bahasa, pergaulan, bahasa, pengantar disekolah dasar, alat komunikasi utama dalam kehidupan sehari-hari serta berfungsi sebagai alat pendukung kebudayaan daerah seperti tercemin dalam berbagai bentuk kesenian dan adat masyarakat Tolaki. Upacara-upacara adat pada umumnya disampaikan dengan bahasa Tolaki.

Istilah interferensi terkandung arti pengaturan kembali pola-pola yang disebabkan oleh masuknya elemen-elemen asing ke dalam bahasa yang berstruktur lebih tinggi, misalnya dalam sistem fonemis, sebagian besar morfologis dan sintaksis, serta beberapa perbendaharaan kata (Rindjin, 1981: 22).

Sebagaimana dikemukakan tersebut dalam berbahasa Indonesia, kata-kata yang dapat dipelajari dalam waktu tertentu, terbatas sekali jumlahnya. Bahasa ibu yang pokok dipelajari oleh seorang anak yang baru pandai berbicara dengan susah payah kata-kata itu merupakan bagian kebudayaan yang ada dilingkungan yang baru dikenalnya. Murid mempelajari pula kata-kata itu untuk memungkinkan membuat kalimat yang diinginkannya. Di sekolah murid belajar menuliskan kata-kata yang diketahuinya dan mengembangkan kata-kata itu secara tidak terbatas sesuai dengan kurikulum sekolah.

Sering kita menyaksikan kenyataan sehari-hari, banyak kalimat bahasa Indonesia yang dituturkan oleh murid-murid tidak lagi memenuhi struktur pola kalimat bahasa Indonesia. Sesuai dengan data di lapangan bahwa masyarakat Lalonggowuna adalah masyarakat pads umumnya sebagai penutur bahasa daerah Tolaki dan pengaruh kuat terhadap bahasa Indonesia sehingga sulit untuk mempelajari bahasa Indonesia sebagai bahasa kedua. Oleh sebab itu, untuk mengetahui ada tidaknya interferensi tersebut dalam bahasa Tolaki ke dalan bahasa Indonesia, maka penulis tertarik untuk melakukan penelitian tentang interferensi fonologis bahasa Tolaki dalam Bahasa Indonesia siswa kelas X SMA Negeri 1 Tongauna.

\section{METODE PENELITIAN}

Metode yang digunakan dalam penelitian ini adalah metode deskriptif kualitatif. Metode ini dimaksudkan untuk menyajikan kenyataan secara objektif sesuai dengan apa yang didapatkan di lapangan, dengan tidak menggunakan angka-angka. Data yang diperlukan dalam penelitian ini adalah data lisan. Data lisan yakni berupa tuturan bahasa Tolaki yang disampaikan dalam bercerita oleh siswa kelas X SMA Negeri 1 Tongauna, yang direkam melalui tape recorder. Teknik yang digunakan dalam penelitian ini adalah: 1) Teknik observasi dilakukan dengan melakukan pengamatan terhadap kegiatan berbahasa murid dengan menggunakan panduan observasi untuk mencatat data dan informasi yang berkenaan dengan masalah penelitian. 2) Teknik 
rekam dilakukan dengan menggunakan alat rekam radio yang diucapkan oleh murid. Teknik ini dimaksudkan untuk memperoleh data tentang interferensi fonologi bahasa daerah Tolaki dalam penggunaan bahasa Indonesia pada siswa kelas X SMA Negeri 1 Tongauna. 3) Teknik wawancara dilakukan dengan mewawancar murid untuk melengkapi data.

Analisis data yang digunakan adalah Teknik analisis data yang dihasilkan dalam penelitian ini adalah interferensi fonologis bahasa Tolaki dalam bahasa Indonesia Murid kelas V SD Negeri 1 Lalonggowuna kalimat bahasa Indonesia dalam bahasa Tolaki yang telah terinterferensi dicocokkan dan dipadankan. Setelah itu, data bahasa tersebut dipaparkan secara tertulis kalimat Bahasa Indonesia yang terinterferensi kedalam bahasa, Tolaki, oleh siswa kelas X SMA Negeri 1 Tongauna Kecamatan Tongauna.

\section{HASIL PENELITIAN}

\section{Penghilangan Fonem di Tengah Dan di Akhir Kata}

Berdasarkan hasil penelitian diperoleh data tentang penghilangan bunyi di akhir kata dalam bahasa Indonesia akibat interferensi bahasa Tolaki oleh siswa kelas X SMA Negeri 1 Tongauna dapat dilihat pada pelafalan kata berikut ini:

Tabel 4.4 Penghilangan fonem

\begin{tabular}{|l|l|}
\hline \multicolumn{1}{|c|}{ Data / Interferensi } & \multicolumn{1}{c|}{ Bahasa Indonesia } \\
\hline Ibu israhat sejenak & Ibu istirahat sejenak \\
$\begin{array}{l}\text { Saya momanci di kali } \\
\text { bersama teman }\end{array}$ & $\begin{array}{l}\text { Saya memancing di kali } \\
\text { bersama teman }\end{array}$ \\
$\begin{array}{l}\text { Nenek meri saya baju } \\
\text { baru }\end{array}$ & $\begin{array}{l}\text { Nenek memberi saya baju } \\
\text { baru }\end{array}$ \\
\hline
\end{tabular}

Berdasarkan data dalam tabel di atas bahwa pada ucapan kata israhat sejenak (bahasa Tolaki) menjadi istirahat sejenak (bahasa Indonesia), ucapan kata momanci (bahasa Tolaki) menjadi memancing (bahasa Indonesia) ucapan kata meri (bahasa Tolaki) menjadi memberi (bahasa Indonesia).

Dalam pelafalan kata israhat (bahasa Tolaki) diucapkan istirahat dalam bahasa Indonesia terjadi interferensi penghilangan fonem /i/ dengan / $t$ / ditengah kata. Kata momanci dalam bahasa Tolaki diucapkan memancing dalam bahasa Indonesia terjadi interferensi penghilangan fonem /n/ dengan /g/ diakhir kata. Kata meri dalam bahasa Tolaki diucapan beri dalam bahasa Indonesia terjadi interferensi penghilangan fonem /b/ tengah kata.

Kata-kata tersebut memperlihatkan fonem bahasa Tolaki akibat interferensi fonologis artinya fonologis bahasa Tolaki mengalami penghilangan fonem meskipun digunakan dalam konteks bahasa Indonesia. Sebab bahasa Tolaki adalah termasuk bahasa vokalik yaitu tidak terdapat atau pada umumnya tidak mengenal konsonan pada posisi akhir sebuah kata atau suku kata.

Penghilangan fonem tersebut dilatarbelakangi oleh pengaruh bahasa daerah Tolaki kedalam bahasa Indonesia sehingga murid-murid yang menggunakan bahasa ibu bahasa Tolaki, setelah menggunakannya kedalam bahasa Indonesia dipengaruhi oleh bahasa Tolaki akibat pengaruh bahasa daerah di masyarakat. Sehingga bunyi yang 
diucapkan berbeda dengan bahasa Indonesia sesuai dengan bahasa lisan dan tulisan bahasa Indonesia. Kata-kata tersebut memperlihatkan bahwa penghilangan fonem bahasa Tolaki yang terjadi akibat interferensi fonologis secara murni artinya aspek fonologis bahasa Tolaki mengalami penghilangan bunyi jika digunakan dalam bahasa lisan.

Ini terjadi karena dalam bahasa Tolaki tidak mengenal fonem /e/ dan konsonan akhir kata sehingga dalam penggunaan bahasa Indonesia terpengaruh oleh bahasa Tolaki. Kata-kata yang mempunyai fonem /e/ berubah menjadi fonem /o/ /a/ dan /i/.

\section{Penggantian dan Penghilangan Fonem}

Berdasarkan hasil penelitian yang diperoleh data tentang penggantian dan penghilangan fonem bahasa Indonesia akibat interferensi bahasa Tolaki oleh murid Sekolah Dasar Negeri 1 Lalonggowuna, dapat dilihat pengucapan kata-kata berikut ini.

Tabel 4.5 Penggantian dan penghilangan fonem

\begin{tabular}{|l|l|}
\hline \multicolumn{1}{|c|}{ Data / Interferensi } & Bahasa Indonesia \\
\hline $\begin{array}{l}\text { Saya momanci di kali } \\
\text { bersama teman }\end{array}$ & $\begin{array}{l}\text { Saya memancing di kali } \\
\text { bersama teman }\end{array}$ \\
Ibu israhat sejenak & Ibu istirahat sejenak \\
\hline
\end{tabular}

Data tentang interferansi fonologis bahasa Tolaki dalam bahasa Indonesia murid Sekolah Dasar Negeri I Lalonggowuna akibat penggantian dan penghilngan fonem sehingga mempengaruhi bahasa Indonesia.

Berdasarkan data dalam tabel di atas, pada ucapan momanci dalam bahasa Tolaki menjadi memancing dalam bahasa Indonesia, ucapan kata israhat sejenak dalam bahasa Tolaki menjadi istirahat sejenak dalam bahasa Indonesia.

Dalam pelafalan kata, momanci pada bahasa Tolaki menjadi memancing dalam bahasa Indonesia, terjadi interferensi penggantian fonem /e/ menjadi /o/ dan penghilangan fonem $/ \mathrm{n} /$ dengan $/ \mathrm{g} /$. penggantian ini terjadi akibat udara yang keluar dari mulut membulat melalui alveolar. Kata israhat sejenak pada bahasa Tolaki menjadi istirahat sejenak dalam bahasa Indonesia terjadi interferensi penggantian fonem /e/ menjadi /a/ dan penghilangan fonem / $t /$ dengan / $/$ /. Penggantian ini terjadi akibat udara dari mulut mendesis melalui alveolar tepi gusi yang keras di belakang akar-akar gigi bawah dan posisi lidah mendatar.

Kata-kata tersebut memperlihatkan bahwa penggantian dan penghilangan fonem bahasa Tolaki yang terjadi adanya interferensi fonologis secara murni artinya, fonologis bahasa Tolaki mengalami penggantian dan penghilangan fonem meskipun digunakan dalam konteks bahasa Indonesia.

Penggantian dan penghilangan fonem tersebut dilatar belakangi oleh pengaruh bahasa daerah Tolaki ke dalam bahasa Indonesia sehingga murid-murid yang menggunakan bahasa ibu bahasa Tolaki, setelah menggunakannya kedalam bahasa Indonesia dipengaruhi oleh bahasa Tolaki, akibat pengaruh bahasa daerah di masyarakat. Sebab bahasa Tolaki adalah termasuk bahasa Vokalik yaitu terdapat atau pada umumnya tidak mengenal konsonan pada posisi akhir sebuah kata atau suku kata. Sehingga kata-kata yang mempunyai fonem /e/ berubah menjadi fonem /o/ /a/ dan /i/. 
ini terjadi karena pengaruh bawaan dari bahasa daerah yang digunakan atau bahasa daerah di masyarakat.

\section{Penggantian Fonem}

Berdasarkan hasil penelitian yang diperoleh data tentang penggantian fonem dalam bahasa Indonesia oleh murid kelas V Sekolah Dasar Negeri 1 Lalonggowuna, dapat dilihat kata-kata berikut ini :

Tabel 4.6 Penggantian Fonem

\begin{tabular}{|c|c|}
\hline Data / interferensi & Bahasa Indonesia BI \\
\hline Nenek langsung momolukku & Nenek langsung memelukku \\
\hline Di sana sojuk pemandangannya & Di sana sejuk pemandangannya \\
\hline $\begin{array}{l}\text { Setelah sampai saya berpoluk dengan } \\
\text { nenek }\end{array}$ & $\begin{array}{l}\text { Setelah sampai saya berpeluk dengan } \\
\text { nenek }\end{array}$ \\
\hline $\begin{array}{l}\text { Di Unaaha itu sangat ramai dan sigar } \\
\text { Salasai makan nenek mengajak } \\
\text { kekobun miliknya }\end{array}$ & $\begin{array}{l}\text { Di Unaaha itu sangat ramai dan segar } \\
\text { Selesai makan nenek mengajak kekebun } \\
\text { miliknya }\end{array}$ \\
\hline Guru bosorta murid pargi berekreasi & Guru beserta murid pergi rekreasi \\
\hline Saya masok membawa oleh-oleh & Saya masuk membawa oleh-oleh \\
\hline $\begin{array}{l}\text { Tiba-tiba nenek momanggil akupun } \\
\text { segera pergi }\end{array}$ & $\begin{array}{l}\text { Tiba-tiba nenek memanggil akupun } \\
\text { segera pergi }\end{array}$ \\
\hline $\begin{array}{l}\text { Borsama, keluarga kami mandi-mandi } \\
\text { di Taipa }\end{array}$ & $\begin{array}{l}\text { Bersama keluarga kami mandi-mandi di } \\
\text { Taipa }\end{array}$ \\
\hline Orang tua saya mongantar di terminal & Orang tua saya mengantar di terminal \\
\hline Ketika liburan sikolah & Ketika liburan sekolah \\
\hline $\begin{array}{l}\text { Nenek mempunyai kobun yang sangat } \\
\text { luas }\end{array}$ & $\begin{array}{l}\text { Nenek mempunyai kebun yang sangat } \\
\text { luas }\end{array}$ \\
\hline Saya dan adik keliling naik sapeda & Saya dan adik keliling naik sepeda \\
\hline Setelah saya tiba nenek mononton TV & Setelah saya tiba nenek menononton TV \\
\hline $\begin{array}{l}\text { Pada saat liburan saya dan teman pargi } \\
\text { berekreasi }\end{array}$ & $\begin{array}{l}\text { Pada saat liburan saya dan teman pergi } \\
\text { berekreasi }\end{array}$ \\
\hline
\end{tabular}

Data interferensi fonologis bahasa Tolaki dalam bahasa Indonesia murid kelasa V Sekolah Dasar Negeri 1 Lalonggowuna akibat penggantian fonem sehingga mempengaruhi bahasa Indonesia. 
Berdasarkan data pada tabel tersebut, bahwa pada ucapan momolukku (bahasa Tolaki) menjadi memelukku (bahasa Indonesia), ucapan kata sojuk (bahasa Tolaki) menjadi sejuk (bahasa Indonesia), ucapan kata berpoluk (bahasa Tolaki) menjadi berpeluk (bahasa Indonesia), ucapan kata sigar (bahasa Tolaki) menjadi segar (bahasa Indonesia), ucapan kata salasai (bahasa Tolaki) menjadi selesai (bahasa Indonesia), ucapan kata boserta (bahasa Tolaki) menjadi beserta (bahasa Indonesia), ucapan kata masok (bahasa Tolaki) menjadi masuk (bahasa Indonesia), ucapan kata momanggil ( bahasa Tolaki) menjadi memanggil (bahasa Indonesia), ucapan kata kata borsama (bahasa Tolaki) menjadi bersama (bahasa Indonesia), ucapan kata kata mongantar (bahasa Tolaki) menjadi mengantar (bahasa Indonesia), ucapan kata sikolah (bahasa Tolaki) menjadi sekolah (bahasa Indonesia), ucapan kata sapeda (bahasa Tolaki) menjadi sepeda (bahasa Indonesia), ucapan kata mononton (bahasa Tolaki) menjadi menonton (bahasa Indonesia), ucapan kata kata porgi (bahasa Tolaki) menjadi pergi (bahasa Indonesia).

Dalam pengucapan kata momolukku (bahasa Tolaki) menjadi memelukku (bahasa Indonesia) terjadi interferensi penggantian fonem /e/ menjadi / o/ . penggantian ini terjadi akibat udara yang keluar dari mulut membulat melalui alveolar. Kata sojuk dalam bahasa Tolaki menjadi sejuk (bahasa Indonesia), terjadi interferensi penggantian fonem /e/ menjadi /i/ .

Penggantian ini terjadi akibat udara yang keluar dari mulut membulat melalui alveolar. Kata berpoluk dalam bahasa Tolaki, menjadi berpeluk dalam bahasa Indonesia terjadi interferensi penggantian fonem /e/ menjadi /i/. penggantian ini terjadi akibat udara yang keluar dari mulut membulat melalui alveolar. Kata sigar dalam bahasa Tolaki menjadi segar dalam bahasa Indonesia, terjadi interferensi penggantian fonem /e/ menjadi /i/. penggantian ini terjadi akibat udara yang keluar dari mulut membulat melalui alveolar. Kata salasai dalam bahasa Tolaki menjadi selesai dalam bahasa Indonesia, terjadi interferensi penggantian fonem /e/ menjadi /a/ penggantian ini terjadi akibat udara yang keluar dari mulut membulat melalui alveolar. Kata bosorta dalam bahasa Tolaki menjadi beserta dalam bahasa Indonesia, terjadi interferensi penggantian fonem /e/ menjadi /o/. penggantian ini terjadi akibat udara yang keluar dari mulut membulat melalui alveolar. Kata masok dalam bahasa Tolaki menjadi masuk dalam bahasa Indonesia, terjadi interferensi penggantian fonem $/ \mathrm{u} /$ menjadi /o/. Penggantian ini terjadi akibat udara yang keluar dari mulut membulat melalui alveolar. Kata momanggil dalam bahasa Tolaki menjadi memanggil dalam bahasa Indonesia, terjadi interferensi penggantian fonem /e/ menjadi /o/. Penggantian ini terjadi akibat udara yang keluar dari mulut membulat melalui alveolar. Kata borsama dalam bahasa Tolaki menjadi bersama dalam bahasa Indonesia, terjadi interferensi penggantian fonem /e/ menjadi /o/. Penggantian ini terjadi akibat udara yang keluar dari mulut membulat melalui alveolar. Kata mongantar dalam bahasa Tolaki menjadi mengantar dalam bahasa Indonesia, terjadi interferensi penggantian fonem /e/ mnjadi /o/. Penggantian ini terjadi akibat udara yang keluar dari mulut membulat melalui alveolar. Kata sikolah dalam bahasa Tolaki menjadi sekolah dalam bahasa Indonesia, terjadi interferensi penggantian fonem /e/ menjadi /i/. Penggantian ini terjadi akibat udara yang keluar dari mulut membulat melalui alveolar. Kata kobun dalam bahasa Tolaki menjadi kebun dalam bahasa Indonesia, terjadi interferensi penggantian fonem /e/ menjadi /o/. Penggantian ini terjadi akibat udara yang keluar dari mulut membulat melalui alveolar. Kata sapeda dalam bahasa Tolaki menjadi sepeda dalam bahasa Indonesia, terjadi interferensi penggantian fonem /e/ menjadi /a/. Penggantian ini terjadi akibat udara yang keluar dari mulut membulat melalui alveolar. 
Kata mononton dalam bahasa Tolaki menjadi menonton dalam bahasa Indonesia, terjadi interferensi penggantian fonem /e/ menjadi /o/. Penggantian ini terjadi akibat udara yang keluar dari mulut membulat melalui alveolar Kata pargi dalam bahasa Tolaki menjadi pergi dalam bahasa Indonesia, terjadi interferensi penggantian fonem /e/ menjadi /a/ Penggantian ini terjadi akibat udara yang keluar dari mulut membulat melalui alveolar.

Kata-kata tersebut di atas memperlihatkan bahwa penggantian fonem bahasa Tolaki yang terjadi akibat interferensi fonologis secara murni. Artinya aspek fonologis bahasa Tolaki mengalami penggantian jika digunakan dalam bahasa lisan.

Penggantian fonem tersebut dilatar belakangi oleh masuknya pengindonesiaan unsur bahasa Tolaki ke dalam bahasa Indonesia. Murid-murid yang menggunakan bahasa ibu bahasa Tolaki, setelah menggunakannya ke dalam bahasa Indonesia dipengeruhi oleh bahasa Tolaki yang terjadi akibat bahasa daerah dimasyarakat, sehingga fonem yang diucapkan berbeda dengan bahasa Indonesia sesuai dengan bahasa tulisan dan lisan bahasa Indonesia.

Sehingga dalam penggunaan bahasa Indonesia terpenbgaruh oleh bahasa Tolaki. Kata-kata yang mempunyai fonem /e/ berubah menjadi fonem /o/ /a/ dan /i/. ini terjadi karena pengaruh bawaan dari bahasa daerah yang digunakan dalam masyarakat sehingga bunyi yang diucapkan berbeda dengan bahasa Indonesia sesuai bahasa lisan dan tulisan bahasa Indonesia.

\section{Interpretasi Hasil Penelitian}

Data interferensi fonologis bahasa Tolaki kedalam bahasa Indonesia lisan murid kelas V Sekolah Dasar Negeri I Lalonggowuna yang berupa data hasil tuntunan bahasa Tolaki yang di sampaikan dalam bercerita yang mempengaruhi bahasa Indonesia lisan dengan tidak berterima oleh bahasa Indonesia baku dan sering terdapat kalimatkalimat bahasa daerah yang dimasukkan ke dalam bahasa lisan murid-murid karena kebiasaanya memakai bahasa dalam bercakap-cakap dengan teman-temannya maupun dengan guru baik pada saat belajar maupun di luar jam belajar dan spontan dipakai dalam bahasa Indonesia lisan.

Interferensi fonologis bahasa Tolaki dalam pemakaian bahasa Indonesia lisan murid kelas V Sekolah Dasar Negeri 1 Lalonggowuna banyak terjadi interferensi penggunaan bahasa Tolaki dalam bahasa Indonesia yang meliputi penghilangan fonem, penggantian dan penghilangan fonem.

\section{SIMPULAN}

Berdasarkan data yang diperoleh dari hasil penelitian pada murid kelas $\mathrm{V}$ Sekolah Dasar Negeri 1 Lalonggowuna diperoleh interferensi bahasa Tolaki dalam bahasa Indonesia akibat terjadinya interferensi yang disebabkan oleh interferensi berupa penghilangan fonem di tengah dan di akhir kata, penggantian dan penghilangan fonem, penggantian fonem. Ini terjadi karena dalam bahasa Tolaki tidak mengenal fonem /e/ dan konsonan pada posisi akhir suku kata sehingga dalam penggunaan bahasa Indonesia terpengaruh oleh bahasa Tolaki. Sehingga kata-kata yang mempunyai fonem /e/ berubah menjadi fonem o, a dan $\mathrm{i}$. 


\section{REFERENCES}

Hamalik. 1996 Kurikulum dan Pembelajaran. Jakarta : Bumi Aksara.

Husain, Akhlan dkk. 1997 Telaah Kurikulum dan buku Teks Bahasa Indonesia. Jakarta : Depdikbud.

Huda, Nuril et.al. 1981 Interferensi Gramatikal Bahasa Madura terhadap Bahasa Indonesia Tulis Murid Kelas VI Jawa Timur. Jakarta : Pusat Pembinaan dan Pengembangan Bahasa.

Koentjaraningrat. 1975 Pengembangan Bahasa Nasional sebagai Unsur Kebudayaan Nasional. Dalam Budaya Jawa No. 82 Tahun Kedelapan, Maret 1975.

Kridalaksana, H. 1984 Kamus Linguistik. Jakarta : Gramedia.

Kridalaksana, H. 1992 Pembentukan Kata dalam Bahasa indonesia. Jakarta : Gramedia.

Konisi, La Yani. Metode penelitian Bahasa: Sistimanka, Metode dan Tekhnik JPBS FKIP Unhalu; Kendari.

Lado. 1964 Pemakaian Kosakata Bahasa Indonesia Murid Kelas VI Sekolah dasar Sumatera Selatan. Jakarta: Pusat Pembinaan dan Pengembangan Bahasa.

Poedjosoedomo. 1978 "Interferensi dan Integrasi dalam Studi Keanekabahasaan ". Majalah Pengajaran Bahasa dan Sastra, Th.IV, No. 2. Jakarta: Pusat Pembinaan clan Pengembangan Bahasa, Departemen Pendidikan dan Kebudayaan.

Parera, Jos Daniel. 1988 Morfologi. Jakarta : Gramedia.

Pateda, Mansoer. 1990 Analisis Kesalahan. Ende: Nusa Indah.

Purwanto, M. Ngalim. 1991 Psikologi Pendidikan. Jakarta: Pedoman Ilmu Jaya.

Ramlan, M. 1985 Morfologi: Suatu Tinjauan Deskriptif. Yogyakarta: C.V. Karyono.

Rasyid, Halipami. 1983 Interferensi Gramatikal Bahasa Minangkabau dalam Bahasa Indonesia Tuhs Murid SD Sumatera Barat. Jakarta : Pusat Pembinaan clan Pengembangan Bahasa.

Roekhan, Nurhadi. 1990 Dimensi — Dimensi dalam Belajar Bahasa Kedua. Bandung: Sinar Biru.

Rindjin, Ketutu et.al. 1981 Interferensi Gramatikal Bahasa Bali dalam Pemakaian Bahasa Indonesia Murid SD di Baft.Depclikbud Pusat Bahasa. 
Rusyana, Yus. 1975 " Interferensi Fonologi pads BI olah anak — anak yang berbahasa Pertama bahasa Sunda Murid SD di Propinsi Jawa Barat". Disertasi. Depdikbud Pusat Bahasa.

Sarni, M. Alisuf. 1995 Psikologi Pendidikan. Jakarta : Pedoman Ilmu Jakarta.

Sarni, Nertin dan Benyamin Tosepu. 1997 Kamus Bahasa Tolaki: Sistim Morfologi, Fonologi Bahasa Tolaki, Kendari. 